\title{
PHYSICO-CHEMICAL PROPERTIES AND SENSORY CHARACTERISTICS OF DEHYDRATED GUAVA CONCENTRATE: EFFECT OF DRYING METH- OD AND MALTODEXTRIN CONCENTRATION
}

\author{
T Mahendran \\ Department of Agricultural Chemistry, Faculty of Agriculture, Eastern University of Sri Lanka, Chenkalady
}

Accepted: $20^{\text {th }}$ May 2010

\begin{abstract}
Dehydration of guava juice into powdered particles gives a considerable reduction in volume and is an effective method of prolonging the shelf life. Therefore, a research study was conducted to determine the effect of different drying methods and the addition of drying aids on the physico-chemical properties and sensory characteristics of dehydrated guava concentrate. Instant guava-drink-powder samples were obtained by dehydrating the concentrated guava juice using freeze drying, spray drying and tunnel drying techniques. Guava juice at $10.5^{\circ}$ Brix was used to prepare the fruit powders. A significant reduction $(p<0.05)$ in titratable acidity of $0.22 \%$ as citric acid and an increase in $\mathrm{pH}$ of 0.44 after drying of guava juice indicated that some acids were lost during the drying process. The oxidative loss of ascorbic acid was considerably lower in freeze drying (18.8\%) compared to tunnel drying (32.2\%). Spray dried powders were obtained from the guava juice with different maltodextrin concentrations as drying aids. When $30 \%$ maltodextrin was added to guava juice, the solubility of powder was $\mathbf{9 5 \%}$ whereas, adding $60 \%$ maltodextrin decreased the solubility to $86 \%$. The chromametric parameters $L^{*}$ (lightness), $a^{*}$ (redness) and $b^{*}$ (yellowness) were found to be significantly $(p<0.05)$ affected by drying methods. Twenty trained sensory panellists ranked the juice prepared from the freeze dried powder as the highest and there were no significant differences $(p>0.05)$ between the juice prepared from spray drying of guava juice upto $50 \%$ added maltodextrin. The freeze dried product had superior nutritional and sensory qualities, however spray dried product was stable and more economical to produce freeflowing guava powder with good stability.
\end{abstract}

Key words: Freeze drying, guava-drink-powder, maltodextrin, spray drying

\section{INTRODUCTION}

Guavas (Psidium guajava) are cultivated in many tropical and subtropical countries for their edible fruit. Guavas are often considered as superfruits being rich in vitamins $\mathrm{A}$ and $\mathrm{C}$ in the pericarp, omega- 3 and -6 polyunsaturated fatty acids in the seeds and especially have high levels of dietary fibre. A single guava fruit weighing 160-170 g contains over four times more of vitamin $\mathrm{C}$ compared to a single orange $(220-230 \mathrm{mg} / 100 \mathrm{~g})$ and also has adequate levels of dietary minerals, potassium, magnesium and an otherwise broad, low-calorie profile of essential nutrients. Guavas contain both major classes of antioxidant pigments such as carotenoids and polyphenols, giving them relatively high dietary antioxidant value among plant foods (Imungi et al. 1994). Most of the guava produced around the world is consumed fresh. Marketing of processed products such as puree, paste, canned slices in syrup or nectar is limited. Clarified guava juice may be more acceptable to the general population and may also be used in manufacturing of clear guava jelly, clear guava powder or a mixed fruit juice blend. There is also a potential to use

*Corresponding author : thevamahen@yahoo.com instant guava powder in formulated drinks, baby foods and confectionary products.

Guava juice has a delicate colour and flavour properties and therefore drying operations need to be carefully designed to preserve the quality. Several methods may be used for production of guava powder, but the most successful methods include freeze drying, foam mat drying and spray drying. Chopda and Banrett (2004) had successfully used the freeze drying to convert guava juice into powder although freeze drying is known to be the most expensive method of drying. Spray drying techniques have been applied to fruit juices. The dehydration time for spray drying is much shorter than those required by other methods such as freeze drying, vacuum drying and tunnel drying and therefore heat damage can be minimized, provided the residence time of the dried particles in the hot zone of the drier is controlled. The extreme hygroscopicity combined with the thermoplastic nature of the food components gives rise to wall deposition problems and hinders subsequent handling of the product.

Maltodextrin and glucose syrups are the usual carriers for orange, lemon, apricot and mango juices and facilitate drying (Masters 1985). Currently, maltodextrin is the most widely used additive to obtain 
fruit juice powders since it satisfies the demand and is also reasonably cheap. The addition of drying aids is necessary during spray drying of fruit juices, adding amount not exceeding the operational limits of the equipment or altering the flavour properties. Fruit juice powders obtained by spray drying present problems in their functional properties such as stickiness and solubility (Bhandari et al. 1997). Much of the published work in this field is of a somewhat general nature. Published data on the effects of drying methods on the physico-chemical and organoleptic properties of the guava powder are limited and fragmentary. Therefore, the objectives of this study were to produce guava powders using freeze drying, spray drying and tunnel drying methods and to evaluate the effects of drying on the quality characteristics of the fruit powders. A consumer preference test was conducted to determine the sensory attributes of the reconstituted guava juice and to compare the final product with the commercial products available in the market.

\section{MATERIALS AND METHODS}

Fully ripe, firm guava ( $P$. guajava var. Allahabad) fruits without bruises were obtained from a commercial horticultural station in Brazil. Fruits were washed in the running water and trimmed. Immature, rotten and damaged fruits were discarded. The fruits were mashed in a fruit mill and transferred to a water bath (Model: Gyromax-929, UK) and the temperature was maintained at $30^{\circ} \mathrm{C}$ with agitation. The pulp was heated at $50^{\circ} \mathrm{C}$ for $30 \mathrm{~min}$. and $500 \mathrm{ppm}$ of pectic enzyme (Pectinex Ultra SP-1, BBI Enzymes, UK) was added to the pulp. The enzyme inactivation was accomplished by heating the pulp to $90^{\circ} \mathrm{C}$ for $5 \mathrm{~min}$. The pulp was pressed and the cloudy juice obtained was treated with fine clarifier Baykisol-30 (hydrogel in association with 15\% active silicic acid) at the concentration of $0.5 \mathrm{ml} / 1$. The treated juice was kept at the temperature of $20 \pm 1^{\circ} \mathrm{C}$ for $30 \mathrm{~min}$ and passed through the microfilters (Applieo Membranes Inc., USA) of $50 \mu \mathrm{m}$ diameter. The clear guava juice was concentrated by reverse osmosis process.

\section{Concentration of guava juice by reverse osmosis} The reverse osmosis was carried out in a plate and frame model (HR-98, Spain) of $0.72 \mathrm{~m}^{2}$ filtration surface composed polysulphone/polyethylene composite layer membranes $(95 \% \mathrm{NaCl}$ rejection). According to Matta et al. (2004), the tests were performed at 20, 40 and 60 bar aiming at the evaluation of the influence of trans-membrane pressure in permeate flux and in the concentrated product. The temperature was maintained at $25 \pm 0.5^{\circ} \mathrm{C}$ and the pump flow rate was kept at $6501 / \mathrm{h}$ throughout the concentration process.

\section{Drying Methods}

1. Freeze drying: The concentrated guava juice was frozen on trays for $5 \mathrm{~h}$ at $-30^{\circ} \mathrm{C}$. After freezing, the samples were transferred to a freeze drier (Model-20 SRC, USA) and dried at $25 \pm 0.5^{\circ} \mathrm{C}$ for $48 \mathrm{~h}$ at $10 \mathrm{mbar} \mathrm{Hg}$ pressure. The powder was obtained by grinding the dried material in a blender and stored in dark glass airtight containers at $20 \pm 1^{\circ} \mathrm{C}$ until further tests were carried out.

2. Spray drying: A laboratory scale cocurrent spray drier (Model-Anhydro LAB S1 209, Italy) with vaned centrifugal atomizer driven by an air turbine at speeds upto $40,000 \mathrm{rpm}$ was used. The inlet temperature of the feed material was $160^{\circ} \mathrm{C}$ and the outlet (product) temperature was set to $80^{\circ}$ $\mathrm{C}$ by regulating the feed pump speed. The feed stock was atomised uniformly but difficulties were encountered owing to the slow flow rate through the gravity feed systems of the drier. Powder was separated from hot air by a cyclone and stored in dark glass airtight containers at $20^{\circ} \mathrm{C}$. Corn maltodextrin DE-10 (Food Grade) was added to the juice before spray drying. Based on the formula developed for spray drying of fruit juices by Bhandari et al. (1993), the following combinations were selected for drying:

1. Guava solids wt 70\% + Maltodextrin wt 30\%

2. Guava solids wt $60 \%+$ Maltodextrin wt $40 \%$

3. Guava solids wt $50 \%+$ Maltodextrin wt $50 \%$

4. Guava solids wt $40 \%$ + Maltodextrin wt $60 \%$

3. Tunnel drying: The tunnel drier (Model 21009 , Wisconsin) was a batch type and the drying temperature was maintained by passing the hot air into the system. An approximately $2 \mathrm{~cm}$ thick layer of concentrated guava juice was spread on cheese cloth and placed over a wire mesh tray which was placed in the tunnel drier for drying. The air temperature was set to $60^{\circ} \mathrm{C}$ for the first $3 \mathrm{~h}$ and then reduced to $50^{\circ} \mathrm{C}$. The total drying time was $12 \mathrm{~h}$ as judged by the appearance of the dried product. The powder was obtained by grinding the dried material in a grinder (VIK-1017, UK) for $3 \mathrm{~min}$ and stored in dark glass airtight bottles at $20 \pm 1^{\circ} \mathrm{C}$.

\section{Nutritional and Sensory Analyses}

Guava juice and powders were analyzed for total soluble solids content using a RFM Refractometer (Model:ATAGO-28E) equipped with a percentage sugar scale and expressed as ${ }^{\circ}$ Brix. Measurement of titratable acidity was conducted using a standard $1 \%$ phenolphthalein solution, titrated against $0.1 \mathrm{~N}$ $\mathrm{NaOH}$ and the result was expressed as grams of anhydrous citric acid per 100g of sample. The $\mathrm{pH}$ was measured using a digital $\mathrm{pH}$ meter (Mettler Toledo, UK) with a glass electrode. The total sugars were determined by standard AOAC (2008) 
method. Vitamin $\mathrm{C}$ was analyzed by oxidereduction reactions using 2,6-dichlorophenol indophenol dye.

Moisture content was determined using a vacuum oven (Model: S/N-29) operated at $70^{\circ} \mathrm{C}$ at 1 bar for $24 \mathrm{~h}$. The bulk density of the powder was determined by measuring the volume of a determined weight of the powder in a $100 \mathrm{ml}$ graduated glass cylinder. The particle density was determined by pycnometry, using toluene at $20^{\circ} \mathrm{C}$. The solubility of the powder was determined by mixing $10 \mathrm{~g}$ powders with $100 \mathrm{ml}$ of distilled water at high speed for $3 \mathrm{~min}$ in a mixer. Then, the solution was centrifuged (Eppendorf C-5702, Japan) at 20,000 x g for $3 \mathrm{~min}$. An aliquot of $50 \mathrm{ml}$ of the supernatant was placed in previously weighed petri dishes and oven dried at $105^{\circ} \mathrm{C}$ for $6 \mathrm{~h}$. Solubility was calculated by difference in weight. The viscosity of the juice was measured in a digital Brookfield viscometer (Model: DVII, USA) at $20^{\circ} \mathrm{C}$ with the spindle No: 2 at 50rpm. The colour of the powder was evaluated by a colorimeter (Model: HSCOL 1348, UK) using the Hunter system. Results were expressed in $L^{*}$ (lightness), a* (redness), b* (yellowness) values. All the assays were performed in triplicate and the data from the dried powders were related to fresh juice by allowing for moisture content whenever necessary.

Twenty trained panelists aged between 18 to 50 years, able to evaluate and differentiate the guava juice samples, were selected to take part in the sensory panel. The panel measured the selected critical attributes such as characteristic aroma, flavour, colour, sweetness, consistency and total acceptability. The attributes were evaluated in a non-structured scale of $10 \mathrm{~cm}$. The tests were carried out in individual sensory booths under the florescent light. Three repetitions were made for each test. The samples were prepared by re-constituting dried powders down to $10.5^{\circ}$ Brix and served to the panellists at $5-7^{\circ} \mathrm{C}$ in white porcelain cups coded by three randomized numbers. Samples were expectorated and judges were given distilled water and crackers to cleanse their palates between samples.

\section{Statistical Analysis}

The design for this experiment was a Completely Randomized Design (CRD). Data were statistically examined by analysis of variance and the means were separated by Duncan's Multiple Range Test. Descriptive statistics was done on sensory attributes and the means were compared using the Tukey's test $(p<0.05)$. All statistical analyses were conducted using SAS version 6.12 (SAS Inst., USA 2002).

\section{RESULTS AND DISCUSSION}

Tables 1 and 2 show the effect of different drying methods on the physico-chemical characteristics of dehydrated guava concentrate.

The moisture content of guava powder ranged from $1.91-2.36 \%$ on dry weight basis. The moisture content of the spray dried powder was lower than that of freeze dried powder. Similar results were reported for pineapple (Abadio et al. 2004), mango (Kalil and Sidel 1994) and orange (Brennan et al. 1991) in the dried fruit powders. Increasing the maltodextrin concentration during spray drying resulted in decrease in moisture content of dried guava powder, probably due to an increase in solids in the feed and reduced amount of free water (Table 1). All the successful experiments in spray drying lead to moisture content lower than 3\% with good freeflowing properties. The inlet and outlet air temperatures are usually the main variables controlling moisture content in the powder. With fruit juices, the nature and concentration of solids in the juice and the type of carrier have also to be considered. The fruit juice to maltodextrin ratio could be increased by decreasing the inlet air temperature and / or by using maltodextrin with low dextrose equivalent (Masters 1990).

Acids are present in fruit juices. During drying, a significant reduction $(p<0.05)$ in titratable acidity of $0.22 \%$ as citric acid and increase in $\mathrm{pH}$ of 0.44 after drying of guava juice indicated that some acids were lost due to evaporation during drying. Askar et al. (1992) reported a noticeable loss in the titratable acidity after freeze drying of guava puree. Papadakis and Bahu (1992) reported that acids with concentrations superior to $10 \%$ of the total dry matter cause difficulties in powder recovery. The oxidative loss of ascorbic acid following tunnel drying was $32.2 \%$ which was higher than following freeze drying $(18.8 \%)$ and spray drying $(21.6 \%)$ with $70 \%$ Guava solids $+30 \%$ Maltodextrin. Ascorbic acid was lost during drying as a result of high temperature and oxidation. Askar et al. (1992) reported a $15 \%$ loss of ascorbic acid in freeze dried guava pulp. Gupta and Nath (1984) also found that freeze dried tomato powder had a higher level of ascorbic acid than spray dried powder. There was an increase in ${ }^{\circ}$ Brix following drying which may be the result of concentration accompanied by the hydrolysis of maltodextrin during drying process. There was a reduction in total sugars in the guava powder, which may be due to non-enzymic browning reactions during drying of guava juice (Table 1).

The various drying methods used in this study were found to have a significant effect on the colour parameters of the guava powder. An increase in 
Hunter $L^{*}$ (lightness) values and $b^{*}$ (yellowness) values following production of guava powder (Table 2) was probably the result of non-enzymic browning during freeze drying which produced a light yellow product. This is in agreement with the results of Tashtoush et al. (2007). They obtained a darker guava freeze dried powder from drying of guava concentrates. The guava juice has high sugar content with low in particulates allowing satisfactory puffing during freeze drying which is responsible for the colour and shiny nature of the powders. All the powders produced by spray drying were a light yellow colour in appearance irrespective of the colour of the feed material. There were no significant differences $(p>0.05)$ between the $\mathrm{L}^{*}$ and $\mathrm{a}^{*}$ (redness) values for powders prepared using different maltodextrin combinations. Chopda and Banrett (2004) reported the production of bright white guava powder after spray drying of puree with maltodextrin. During spray drying a* decreased as $\mathrm{L}^{*}$ increased because oxidation of pigments increasingly revealing the white colour of the maltodextrin. Due to the long drying process at high temperatures, the guava powder produced by tunnel drying had a golden yellow colour but was very sticky and difficult to remove from the trays and grind. It was observed that the deteriorative changes in quality were more pronounced during the tunnel drying of guava juice.

The physical properties such as moisture content, bulk density, particle density, wetting, dispersion, solubility, particle size and distribution of guava powder were related to ease of reconstitution. These properties are influenced by the nature of the feed (solid content, viscosity and temperature) and operational conditions. The bulk and particle densities of the dried guava powders were also compared (Table 2). The tunnel dried powder had significantly higher $(p<0.05)$ bulk density than spray dried powder. However, the values found for both densities were lower than those found by Borges et al. (2002) which were 0.75 and $2.47 \mathrm{~g} / \mathrm{cm}^{3}$ for bulk density and particle density, respectively. Bhandari et al. (1993) found values for bulk density of 0.47$0.58 \mathrm{~g} / \mathrm{cm}^{3}$ for temperate climate fruit powders. An increase in maltodextrin concentration during spray drying led to a significant decrease $(p<0.05)$ in both bulk and particle densities of the powder compared to freeze and tunnel drying. This is probably due to low moisture content of the dried powders. The opposite was found by Borges et al. (2002) for a similar product dried by spray drying using pressure nozzle for liquid atomization. The true density was lower at high atomisation speed, resulting in more porous products due to incorporation of air in the feed and also between the small particles. Tunnel dried powder had the highest values for bulk and particle densities, but gave the lowest viscosity compared with the other drying methods (Table 2). The viscosity and stickiness of the spray dried powders vary according to the composition, decreasing when the proportion of the guava juice solids is increased. Some morphological and dimensional differences occurred in the powder properties due to the differences in drying methods. The spray dried powders were spherical as expected. A high ratio (0.82-0.87) of surface to volume for a sphere and the large amount of small spheres were found in the powders. The freeze dried and tunnel dried powders had complex forms because they were ground after dehydration. The tunnel dried powder was very compact and formed into large pieces of $100-150 \mu \mathrm{m}$ diameters.

Spray drying of heat sensitive food material containing a high proportion of hygroscopic sugars is often associated with problems of non-uniform atomization and wall deposition. It was observed that the stickiness decreased as a function of maltodextrin concentration for the spray drying of guava juice. Brennan et al. (1991) reported the wall deposition problem encountered in the spray drying of orange juice concentrate and indicated that wall deposition is dependent on the thermoplasticity and hygroscopicity of the powders. Wall deposition was not a serious problem with guava juice; the product was fine, free-flowing powder of light yellow colour. However, most of the product remained in the lower part of the chamber instead of reaching the cyclone collector. This powder could readily be dislodged by knocking the chamber walls, suggesting that the air broom or vibrating hammer devices available on larger spray driers would overcome this problem. When maltodextrin was added to juice, it formed a film around the solids in the feed that facilitated the production of non-hygroscopic and fine flowing powder. This behaviour occurs because the particles are better dispersed, while decreases cohesive force between them. Based on these results, it can be stated that the addition of maltodextrin to guava juice caused changes in the microstructure of the dehydrated powder, influencing the functional characteristics of the powder. Adhikari et al. (2004) stated that the addition of maltodextrin reduced the stickiness and prevented the caking of dried fruit powders during storage.

The spray dried powders produced in this research were stable at room temperature of $20 \pm 1^{\circ} \mathrm{C}$. The fruit powders were reconstituted after blending with water at the ratio of 1:10 at the room temperature of $20 \pm 1^{\circ} \mathrm{C}$. Solubility problems occur when foods are subjected to higher temperatures, especially in products with high concentration of solids. The freeze dried powder could be reconstituted instantly with water at room temperature. In general, a reduction in maltodextrin concentration improved the 
solubility. When $30 \%$ maltodextrin was added to guava juice, the solubility of powder was $95 \%$ whereas adding $60 \%$ maltodextrin decreased the solubility to $86 \%$. These results are in agreement with Chauca et al. (2004), who reported that higher concentrations of drying carriers resulted in low solubility of the dried mango powder. With respect to the results obtained in a previous study under similar conditions by Borges et al. (2002), the solubility was $95 \%$ with $60 \%$ Guava solids $+40 \%$ Maltodextrin. The reconstituted drink made from the fruit powder with $60 \%$ maltodextrin was not clear because the maltodextrin exceeded the solid limits suggested for making clear solutions. Maltodextrin as a carrier in juice dehydration by spray drying is one of the most utilized substances due to its physical properties such as solubility in water. However, due to the change in structure of the powder, it influences the functional solubility. The properties of the powdered guava particles change as a function of maltodextrin concentration; the higher concentrations leading to decreased solubility of the powder in water. To maintain the guava powder quality during storage, the physicochemical state of the dried product has to be maintained for as long as possible. Any change in its structure not only changes the physico-sensorial attributes but also it may have some quality deteriorating consequences such as increase in rate of chemical reactions, structural damage and changes in microbial quality.

Ready-to-serve (RTS) guava nectars were prepared from fruit powders and were compared with those prepared from fresh juice. The fruit powders were reconstituted at the ratio of $1: 10$ by adding water to the final total soluble solid contents of $10.5^{\circ}$ Brix. All the sensory panellists had tasted guava fruit or drink before and all of them gave higher scores for its taste. Scores assigned for each sensory attribute were totalled for each sample to give a value for total acceptability (Table 3 ).

Nectar made from the freeze dried concentrated juice contained the highest ascorbic acid content of $117 \mathrm{mg} / 100 \mathrm{ml}$ primarily due to greater proportion of guava powder used in the final drink whereas the commercial nectar contained low level of ascorbic acid $(29 \mathrm{mg} / 100 \mathrm{ml})$. There was no significant difference $(p>0.05)$ between the acceptability of the fresh juice and the reconstituted freeze dried powder. This indicated minimal flavour loss during freeze drying. Most of the panellists preferred the flavour and sweetness of the freeze dried nectar and gave scores accordingly. Spray dried powder produced from $40 \%$ guava juice was unacceptable to $78 \%$ of the panellists because of the thick consistency and off-flavour. This may be due to the addition of maltodextrin at higher concentration than the desirable level from the sensory standard point. Overall, $88 \%$ of the panellists were either very satisfied or satisfied with reconstituted guava nectar and only $5 \%$ disliked it. The remainder of the panellists expressed neutral opinion. Our results are in contrast to the finding of Askar et al. (1992). They reported a significant loss in quality in guava powder which was unacceptable by most of the consumers. This may be due to the difference in sensory method used by Askar et al. (1992) and more diverse ethnicity of the consumers participated in the sensory analysis.

\section{CONCLUSIONS}

This study examined the feasibility of using different drying methods to produce instant guava powder of acceptable quality at reasonable cost. Concentrated guava juice without additives cannot be

Table 1: Effect of Different Drying Methods on the Chemical Characteristics of Dehydrated Guava Concentrate

\begin{tabular}{|c|c|c|c|c|c|c|}
\hline Treatments & $\begin{array}{l}\text { Moisture } \\
(\%)\end{array}$ & $\mathbf{p H}$ & $\begin{array}{l}\text { Titratable } \\
\text { acidity (\%) } \\
\text { (as citric acid) }\end{array}$ & $\begin{array}{l}\text { Total } \\
\text { sugars }(\%)\end{array}$ & $\begin{array}{l}\text { Vitamin C } \\
(\mathrm{mg} \%)\end{array}$ & ${ }^{\circ}$ Brix \\
\hline Concentrated Fresh Guava juice & $87.4 \pm 1.21$ & $4.12 \pm 0.12$ & $0.52 \pm 0.01$ & $9.84 \pm 0.10$ & $996.9 \pm 1.80$ & $12.5 \pm 0.17$ \\
\hline Freeze-dried & $2.36 \pm 0.04^{\mathrm{c}}$ & $4.27 \pm 0.10^{\mathrm{a}}$ & $0.49 \pm 0.01^{\mathrm{c}}$ & $8.61 \pm 0.13^{\mathrm{c}}$ & $809.5 \pm 1.72^{\mathrm{c}}$ & $35.4 \pm 0.22^{\mathrm{c}}$ \\
\hline Tunnel-dried & $1.91 \pm 0.03^{\mathrm{a}}$ & $4.48 \pm 0.11^{\mathrm{b}}$ & $0.37 \pm 0.02^{b}$ & $8.15 \pm 0.12^{b}$ & $675.4 \pm 2.14^{\mathrm{a}}$ & $30.7 \pm 0.19^{b}$ \\
\hline \multicolumn{7}{|l|}{ Spray-dried } \\
\hline 1. Guava solids $70 \%+$ Maltodextrin $30 \%$ & $2.24 \pm 0.04^{\mathrm{b}}$ & $4.38 \pm 0.10^{b}$ & $0.39 \pm 0.01^{\mathrm{b}}$ & $8.30 \pm 0.12^{\mathrm{b}}$ & $782.1 \pm 2.1^{b}$ & $33.4 \pm 0.21^{\mathrm{bc}}$ \\
\hline 2. Guava solids $60 \%+$ Maltodextrin $40 \%$ & $2.21 \pm 0.03^{\mathrm{b}}$ & $4.44 \pm 0.09^{\mathrm{b}}$ & $0.36 \pm 0.02^{\mathrm{b}}$ & $8.24 \pm 0.09^{b}$ & $768.3 \pm 1.9^{b}$ & $32.1 \pm 0.20^{\mathrm{bc}}$ \\
\hline 3. Guava solids $50 \%+$ Maltodextrin $50 \%$ & $2.17 \pm 0.02^{\mathrm{b}}$ & $4.47 \pm 0.11^{\mathrm{b}}$ & $0.35 \pm 0.01^{\mathrm{b}}$ & $8.17 \pm 0.10^{\mathrm{b}}$ & $741.2 \pm 2.0^{\mathrm{b}}$ & $31.5 \pm 0.24^{\mathrm{b}}$ \\
\hline 4. Guava solids $40 \%+$ Maltodextrin $60 \%$ & $2.14 \pm 0.03^{\mathrm{b}}$ & $4.56 \pm 0.08^{\mathrm{bc}}$ & $0.30 \pm 0.02^{\mathrm{a}}$ & $7.83 \pm 0.11^{\mathrm{a}}$ & $681.3 \pm 2.3^{\mathrm{a}}$ & $27.4 \pm 0.21^{\mathrm{a}}$ \\
\hline
\end{tabular}

Values represent the average of triplicate analytical measurements.

Values in the same column bearing different letters are significantly different. 
Table 2: Effect of different drying methods on the Physical characteristics of Dehydrated Guava Concentrate

\begin{tabular}{|c|c|c|c|c|c|c|c|}
\hline Treatments & $\begin{array}{l}\text { Bulk density } \\
\mathrm{g} / \mathrm{cm}^{3}\end{array}$ & $\begin{array}{l}\text { Particle den- } \\
\text { sity } \mathrm{g} / \mathrm{cm}^{3}\end{array}$ & $\begin{array}{l}\text { Solubility } \\
(\%)\end{array}$ & $\begin{array}{l}\text { Viscosity } \\
(\mathrm{mp})\end{array}$ & $\begin{array}{l}\text { Hunter } \\
\mathbf{L}^{*}\end{array}$ & $\begin{array}{l}\text { Colour } \\
\mathbf{a}^{*}\end{array}$ & $\begin{array}{l}\text { Values } \\
\text { b }^{*}\end{array}$ \\
\hline Concentrated Fresh Guava juice & & & & & 36.9 & 2.58 & 10.34 \\
\hline Freeze-dried & $0.65^{\mathrm{c}}$ & $1.71^{\mathrm{c}}$ & $96.2^{\mathrm{c}}$ & $219.1^{\mathrm{b}}$ & $81.8^{\mathrm{b}}$ & $1.91^{\mathrm{c}}$ & $31.36^{\mathrm{d}}$ \\
\hline Tunnel-dried & $0.69^{\mathrm{d}}$ & $1.79^{\mathrm{c}}$ & $86.3^{\mathrm{a}}$ & $196.7^{\mathrm{a}}$ & $73.8^{\mathrm{a}}$ & $4.29^{\mathrm{d}}$ & $17.91^{\mathrm{a}}$ \\
\hline \multicolumn{8}{|l|}{ Spray-dried } \\
\hline 1. Guava solids $70 \%+$ Maltodextrin $30 \%$ & $0.61^{\mathrm{b}}$ & $1.64^{\mathrm{b}}$ & $95.1^{\mathrm{c}}$ & $226.9^{\mathrm{bc}}$ & $84.4^{\mathrm{b}}$ & $1.66^{\mathrm{b}}$ & $26.18^{\mathrm{c}}$ \\
\hline 2. Guava solids $60 \%+$ Maltodextrin $40 \%$ & $0.60^{\mathrm{b}}$ & $1.60^{\mathrm{b}}$ & $94.2^{\mathrm{bc}}$ & $233.2^{\mathrm{bc}}$ & $86.6^{\mathrm{b}}$ & $1.61^{\mathrm{b}}$ & $24.28^{\mathrm{c}}$ \\
\hline 3. Guava solids $50 \%+$ Maltodextrin $50 \%$ & $0.57^{\mathrm{b}}$ & $1.54^{\mathrm{b}}$ & $92.9^{\mathrm{b}}$ & $240.8^{\mathrm{c}}$ & $88.1^{\mathrm{bc}}$ & $1.54^{\mathrm{b}}$ & $22.97^{\mathrm{bc}}$ \\
\hline 4. Guava solids $40 \%+$ Maltodextrin $60 \%$ & $0.54^{\mathrm{a}}$ & $1.49^{\mathrm{a}}$ & $86.1^{\mathrm{a}}$ & $249.1^{\mathrm{d}}$ & $91.3^{\mathrm{c}}$ & $1.43^{\mathrm{a}}$ & $20.13^{\mathrm{b}}$ \\
\hline
\end{tabular}

L* - Lightness, a* - Redness and b* - Yellowness.

Values represent the average of triplicate analysis.

Values in the same column bearing different letters are significantly different.

Table 3: Effect of Different Drying Methods on the Sensory Characteristics of the Reconstituted Guava Drink

\begin{tabular}{|c|c|c|c|c|c|c|}
\hline \multirow[b]{2}{*}{ Treatments } & \multicolumn{5}{|c|}{ Sensory quality scores } & \multirow[b]{2}{*}{$\begin{array}{l}\text { Total } \\
\text { acceptability }\end{array}$} \\
\hline & Colour & Sweetness & Aroma & Flavour & Consistency & \\
\hline Concentrated Fresh Guava juice & $8.9^{c}$ & $7.8^{\mathrm{c}}$ & $8.3^{\mathrm{c}}$ & $8.9^{\mathrm{c}}$ & $8.2^{\mathrm{cd}}$ & $42.1^{\mathrm{c}}$ \\
\hline Freeze-dried & $8.7^{\mathrm{c}}$ & $7.8^{\mathrm{c}}$ & $8.0^{\mathrm{bc}}$ & $8.8^{\mathrm{c}}$ & $7.9^{\mathrm{c}}$ & $41.2^{\mathrm{b}}$ \\
\hline Tunnel-dried & $7.4^{\mathrm{a}}$ & $6.5^{\mathrm{a}}$ & $6.2^{\mathrm{a}}$ & $6.4^{\mathrm{a}}$ & $7.0^{\mathrm{b}}$ & $33.5^{\mathrm{a}}$ \\
\hline \multicolumn{7}{|l|}{ Spray-dried } \\
\hline 1. Guava solids $70 \%+$ Maltodextrin $30 \%$ & $8.4^{\mathrm{b}}$ & $7.6^{\mathrm{b}}$ & $7.8^{\mathrm{b}}$ & $8.0^{\mathrm{b}}$ & $7.6^{\mathrm{b}}$ & $9.4^{\mathrm{b}}$ \\
\hline 2. Guava solids $60 \%+$ Maltodextrin $40 \%$ & $8.2^{\mathrm{b}}$ & $7.5^{\mathrm{b}}$ & $7.6^{\mathrm{b}}$ & $7.9^{\mathrm{b}}$ & $7.4^{\mathrm{b}}$ & $38.6^{\mathrm{b}}$ \\
\hline 3. Guava solids $50 \%+$ Maltodextrin $50 \%$ & $8.1^{\mathrm{b}}$ & $7.4^{\mathrm{b}}$ & $7.4^{\mathrm{b}}$ & $7.6^{\mathrm{b}}$ & $7.1^{\mathrm{b}}$ & $37.6^{\mathrm{b}}$ \\
\hline 4. Guava solids $40 \%+$ Maltodextrin $60 \%$ & $7.8^{\mathrm{a}}$ & $6.8^{\mathrm{ab}}$ & $6.7^{\mathrm{a}}$ & $7.0^{\mathrm{ab}}$ & $6.3^{\mathrm{a}}$ & $34.6^{\mathrm{a}}$ \\
\hline
\end{tabular}

Values are the means of two replications with sensory evaluation completed by 20 trained panellists.

Values in the same column bearing different letters are significantly different.

satisfactorily spray dried because of the hygroscopic and thermoplastic nature of the product. Freeze drying produced the best quality guava powder in terms of colour, flavour and ascorbic acid retention though it was quite hygroscopic in nature. Spray dried product had bright and attractive colour in comparison to the darker tunnel dried product. The latter was rated poorly in the taste panel assessments possessing a distinct off-flavour. Spray drying produced stable powders at room temperature of $20 \pm 1^{\circ} \mathrm{C}$. Maltodextrin proved to be the effective additive, reducing the wall deposition markedly and producing a product of acceptable flavour and with good free-flowing properties. The freeze dried powder showed higher pigment stability than the spray dried powder. The colour parameters $\mathrm{L}^{*}, \mathrm{a}^{*}$ and $\mathrm{b}^{*}$ were found to be significantly affected by drying methods. The spray dried, reconstituted juice was slightly lacking in flavour compared to freshly prepared juice but was preferred to tunnel dried material. This assessment reflects the heat damage indicated by the chemical analyses, consequently the poor quality of the product does not recommend the application of tunnel drying. Because freeze drying is an expensive method to apply commercially, spray drying may be the best alternative for producing guava powder with good stability. In each case, a compromise must be found to the fruit juice to additive ratio, drying yield and cost of production. The development of an instant guava juice powder not only reduces the shipping cost but also curtails wastage because guava powder is more stable than its liquid counterpart.

\section{REFERENCES}

Abadio FDB, Domingues AM, Borges SV and Oliveira VM 2004 Physical properties of powdered pineapple (Ananas comosus) juice effect of maltodextrin concentration and atomization speed. Journal of Food Engineering. 64: 285-287.

Adhikari B, Howes T, Bhandari BR and Troung V 2004 Effect of addition of maltodextrin on 
drying kinetics and stickiness of sugar and acid-rich foods during convective drying experiments and modelling. Journal of Food Engineering. 64: 53-68.

AOAC 2008 Official Methods of Analysis of AOAC International. $18^{\text {th }}$ ed. Association of Official Analytical Chemists, USA.

Askar A, El-Sanahy SK, Barrnett $\mathrm{M}$ and Salema NA 1992 Production of instant guava drink powder. Food Technology. 46(5): 154-161

Bhandari BR, Data N and Howes T 1997 Problems associated with spray drying of sugarrich foods. Drying Technology. 15(2): 671684.

Bhandari BR, Senoussi A, Dumoulin ED and Lebert, A. 1993 Spray drying of concentrated fruit juices. Drying Technology. 11(5): 10811092.

Borges SV, Reis ALS, Jorge EC, Pinto PR and Oliveira V 2002 Judo de frutas tropicales deshidratados por spray drying. Alimentaria. 334: 125-130.

Brennan JG, Herrera K and Jowitt R 1991 A study on the factors affecting the spray drying of orange juice. Journal of Food Technology. 26: 314-321.

Chauca MC, Stringheta PC, Sardigna L and CalVidal J 2004 Mango juice dehydration by spray drying using different carriers and functional characterization. Proceedings of the $14^{\text {th }}$
International Drying Symposium, Sao Paulo, Brazil. 22-25 ${ }^{\text {th }}$ August 2004. pp. 205-212.

Chopda CA and Banrett DM 2004 Optimization of guava juice and powder production. Proceedings of the 14th International Drying Symposium, Sao Paulo, Brazil. 22-25th August 2004. pp. 1764-1789.

Gupta RG and Nath N 1984 Drying of tomatoes. Journal of Food Science and Technology. 21: 372-376.

Imungi JK, Schefield H and Saint-Hilslare U 1994 Physical-chemical changes during extraction and clarification of guava juice. Chemistry and Technology. 7: 33-41.

Kalil UL and Sidel TP 1994 Spray drying of mango juice concentrate. Mesopotamia Journal of Agriculture. 29(1): 81-89.

Masters K 1985 Spray Drying Hand Book. 4th ed. Longman Scientific and Technical, England. pp. 255-258.

Masters K 1990 Spray drying of liquid foods. Chemical Engineering. 367: 149-158.

Matta VM, Moretti RH and Cabral LMC 2004 Microfiltration and reverse osmosis for clarification and concentration of acerola juice. Journal of Food Engineering. 64: 477-482.

Papadakis S and Bahu R 1992 The sticky issues of drying. Drying Technology. 10(4): 76-91.

Tashtoush DK, Vividas UR and Mujumdar GT 2007 Effect of spray drying variables on the physico-chemical characteristics of guava powder. Drying Technology. 29: 288-290. 